\title{
Impact of Climate Change on Flowering and Fruiting Times
}

\section{of Nunavut Arctic Plants}

\author{
by Zoe Panchen
}

\section{INTRODUCTION}

$\mathrm{P}$ HENOLOGY IS THE TIMING OF nature's seasonal events such as the arrival of migratory birds, the emergence of insects, and my particular research interest, the timing of flowering and fruiting (Rathcke and Lacey, 1985). Because these phenological events are seasonal, they are often influenced by temperature. This is certainly the case for many plant species in which the initiation of flowering occurs when cumulative daily temperatures reach a species-specific number of degree days above a threshold (Bernier and Périlleux, 2005; Kimball et al., 2014). Hence, with warmer temperatures, many plant species, including Arctic species, advance their flowering time and flower earlier (Molau, 1997; Thórhallsdóttir, 1998; Abu-Asab et al., 2001; MillerRushing and Primack, 2008). The responsiveness of a species' flowering or fruiting time to temperature, called temperature-sensitivity, is measured in days per ${ }^{\circ} \mathrm{C}$. A negative value indicates an advance in flowering or fruiting time with warmer temperatures. As the climate warms, one might also expect flowering and fruiting to occur earlier over time, and this change is often measured in days per decade. Again, a negative value indicates an advance in flowering or fruiting time over the years.

Long-term phenology monitoring and herbarium specimens (pressed plants) are two sources of historical flowering and fruiting phenology data that record the timing of flowering or fruiting at a specific location in a specific year (Fig. 1) and can be used to assess changes in flowering and fruiting times over the years (Fitter et al., 1995; MillerRushing et al., 2006; Bock et al., 2014; Davis et al., 2015). By correlating these records with historical temperature records from weather stations, we can also assess the temperature-sensitivity of species' flowering or fruiting phenology to climate change (Molau et al., 2005; Panchen et al., 2012; Calinger et al., 2013).

My research objectives were to determine (1) whether flowering and fruiting times of Arctic plants in Nunavut, Canada, are changing with climate change, (2) the phenological temperature-sensitivity of Nunavut Arctic plants, and (3) how the climate in Nunavut is changing. The first step in my research was to understand the phenology of Nunavut Arctic plants, and for that I established sites at two

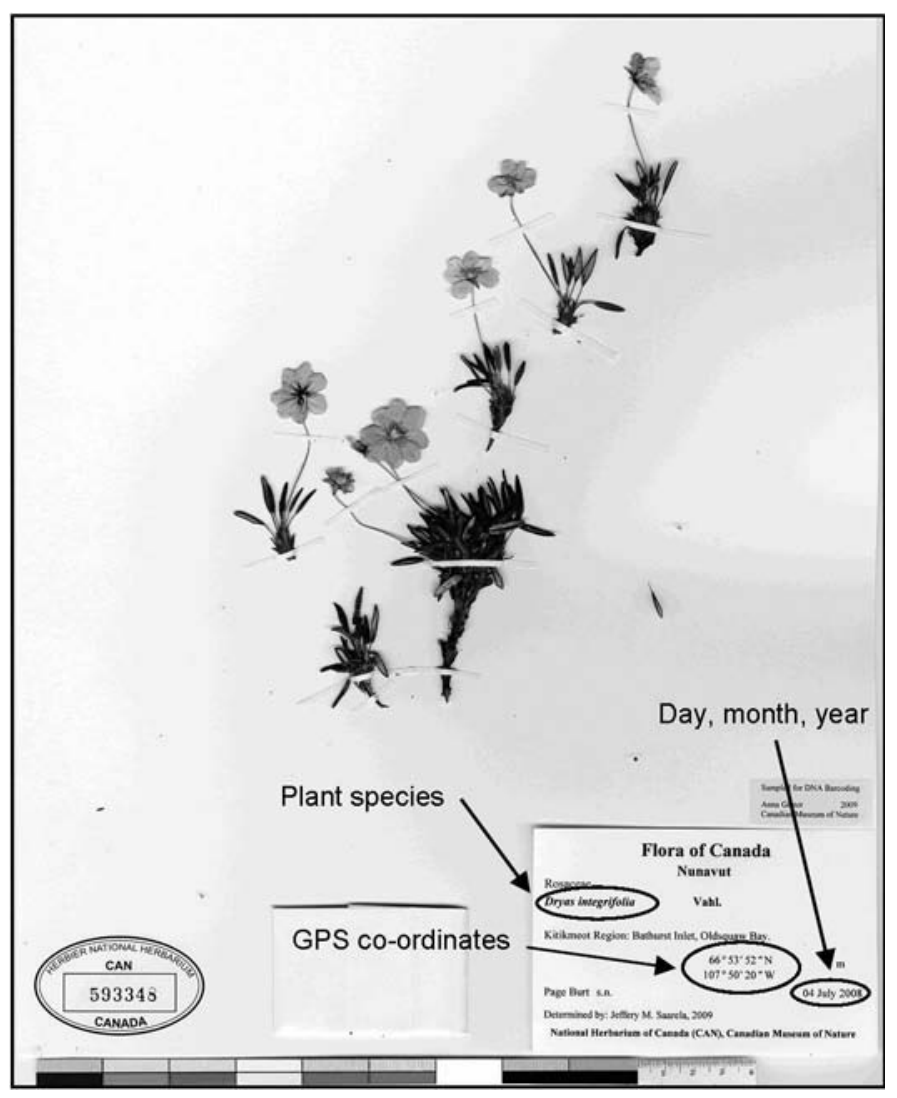

FIG. 1. Herbarium specimen of mountain avens (Dryas integrifolia), accession number CAN 593348, collected in flower in Nunavut, Canada, with a label recording the location (GPS co-ordinates) and date (day, month, year) of collection. The information recorded on the herbarium specimen can be used in phenology and climate change studies to assess the impact of climate change on the timing of flowering and fruiting. Scan of herbarium specimen courtesy of the National Herbarium of Canada, Canadian Museum of Nature.

field locations to monitor the flowering and fruiting times of a broad spectrum of plant species commonly found in Nunavut. I used my monitoring data to inform my decisions on which species to use in my subsequent studies on the impacts of climate change on flowering and fruiting times of Nunavut Arctic plants and to aid in interpreting the results from those studies. I studied the impact of climate 


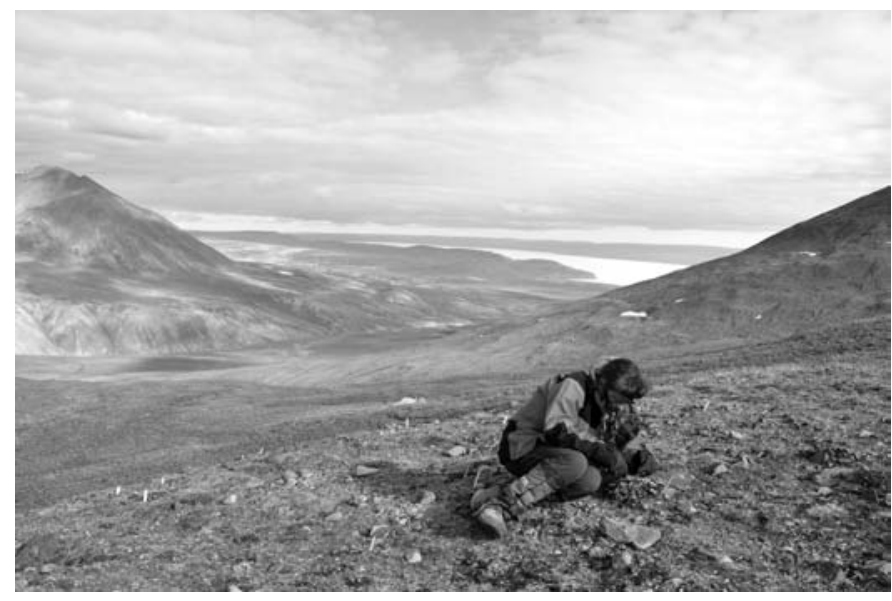

FIG. 2. Zoe Panchen counting the number of open flowers on tagged plants to determine start, peak, finish, and duration of flowering of purple saxifrage (Saxifraga oppositifolia) at Lake Hazen, Quttinirpaaq National Park, Ellesmere Island, Nunavut Canada. (Photo: C. Casey)

change on Nunavut Arctic plants using three different methods: long-term phenological monitoring; herbarium specimens as a source of historical phenological records; and an elevation gradient, with its associated temperature gradient, as a proxy for climate change. Broadly speaking, my research employed different spatial and temporal scales to assess Nunavut Arctic plant responses to climate change and the implications of those responses.

\section{RESEARCH METHODS AND FINDINGS}

\section{Phenology Monitoring Study}

I followed the flowering phenology at Lake Hazen, Quttinirpaaq National Park, Ellesmere Island $\left(82^{\circ} \mathrm{N}\right)$ and Iqaluit, Baffin Island $\left(64^{\circ} \mathrm{N}\right)$ in 2013 and 2014 (Figs. 2 and 3). I monitored 50 common Nunavut Arctic plant species, 20 of them at both Lake Hazen and Iqaluit. Twice per week, I counted the number of flowers on tagged plants of each species at multiple sites at one or both locations (30 tagged plants per site). I determined the start, peak, finish, and duration of flowering by comparing these counts. For example, the start of flowering was the date when the flower count changed from zero flowers to one or more flowers, and peak flowering, the date with the maximum flower count. For each of the 20 species monitored at both locations, I compared flowering times of conspecific plants between the two locations and between different microclimates at each location. I found, much to my surprise, that many of the plants at Lake Hazen flowered earlier than their conspecifics at Iqaluit (Panchen and Gorelick, 2016). I was expecting the opposite, given that Iqaluit's growingseason temperatures are $2^{\circ} \mathrm{C}$ warmer than Lake Hazen's (Environment Canada, 2016) and that plants tend to flower earlier with warmer temperatures. I therefore suggest that the plants at Lake Hazen are evolutionarily adapted to the colder, shorter growing season farther north (Clausen et al., 1941; Weber and Schmid, 1998; Wagner and Simons, 2009; Anderson et al., 2012). My analysis of the flowering times at the Lake Hazen and Iqaluit locations showed that the microclimates at a location had a much more significant relationship with the timing of flowering than either the location or the elevation. I therefore suggest that these plants showed phenotypic plasticity across microclimates at a location.

\section{Long-term Phenology Monitoring Study}

For the last 20 years (1995-2014), Parks Canada staff have been monitoring the flowering and fruiting times of two common Arctic plant species at Tanquary Fiord, Quttinirpaaq National Park (Fig. 3), not far from Lake Hazen. My analysis of the long-term phenology monitoring data from Tanquary Fiord showed that the midsummerflowering mountain avens (Dryas integrifolia Vahl) has significantly advanced its flowering and fruiting times over the 20 years of monitoring, while the early spring-flowering purple saxifrage (Saxifraga oppositifolia L.) has not (Panchen and Gorelick, 2015). I found that the flowering time of mountain avens was twice as sensitive to temperature as that of purple saxifrage. Similarly, mountain avens fruiting time was significantly temperaturesensitive, but that of purple saxifrage was not. The 25 -year (1989-2014) weather station records from Tanquary Fiord indicate that late growing season (July) monthly temperatures and some late autumn and winter (September, October, January, and March) monthly temperatures have risen significantly, while early growing-season (May and June) monthly temperatures have not. This pattern is in line with the pan-Arctic pattern of climate change being observed (McBean, 2005; Stocker et al., 2013). The different advances in flowering and fruiting times of these two species, which flower at different times during the growing season, reflect the fact that July temperatures are rising more than May and June temperatures.

\section{Herbarium Specimen Study}

Using my phenology monitoring data from Lake Hazen and Iqaluit, I chose 23 common Arctic plant species that have (1) flowering durations of less than three weeks, (2) easily distinguishable flowering and seed-dispersing stages, and (3) at least 50 herbarium specimens collected in Nunavut. I recorded the flowering times and seed dispersal times documented on approximately 3500 herbarium specimens collected from across the 2.1 million $\mathrm{km}^{2}$ area of Nunavut (Fig. 3). From these historical records, I determined that seed dispersal times have advanced at double the rate of flowering times over the 120 -year period (1896-2015) of herbarium specimen collection in Nunavut (Panchen and Gorelick, in press). 


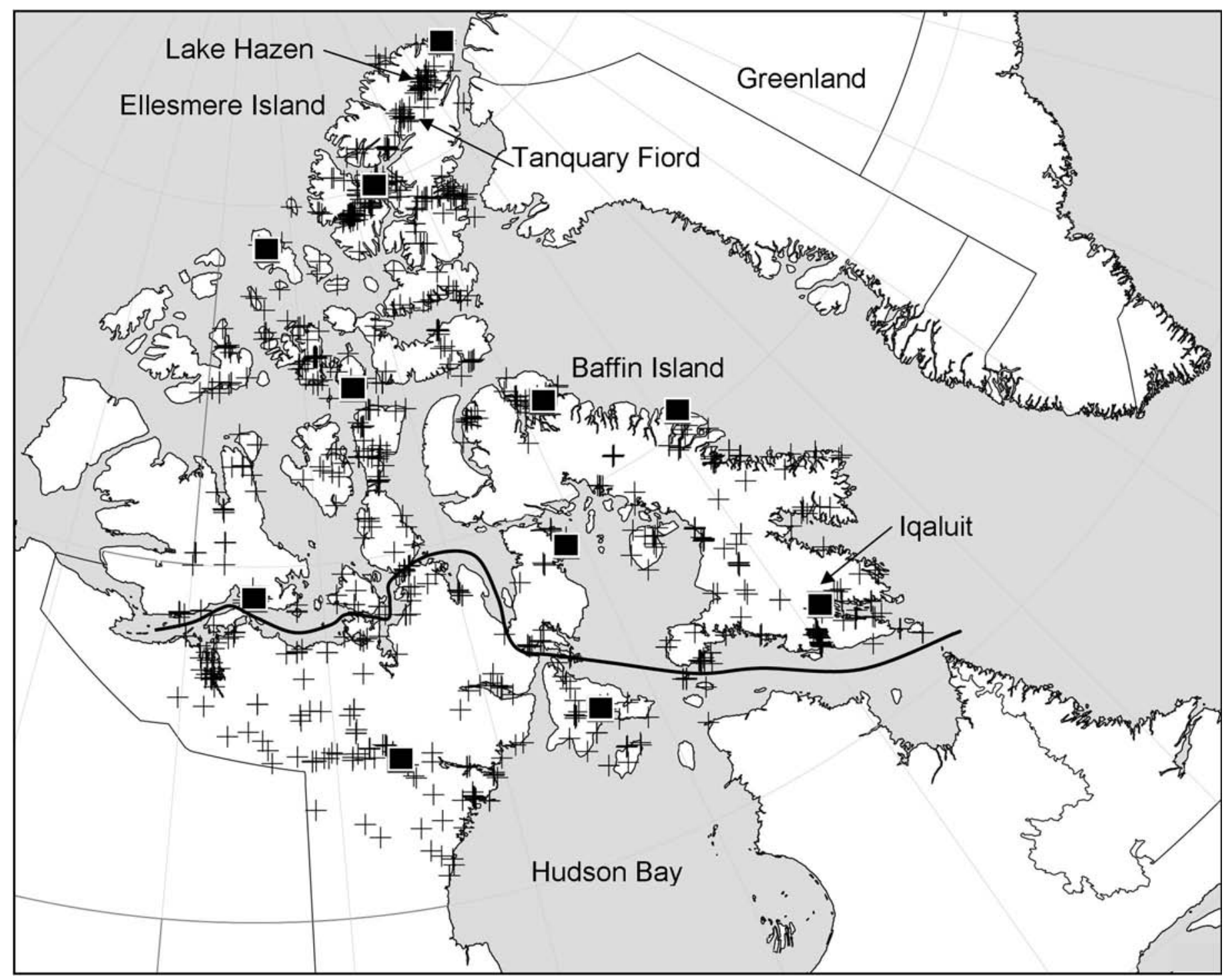

FIG. 3. Map of collection locations and weather stations referred to in the study. Plus signs (+) show sites across Nunavut where herbarium specimens were collected in flower, and solid squares ( $\square$ ) show the locations of Environment Canada weather stations used in the study. Historical monthly temperatures from these stations and recorded flowering times from the herbarium specimens were used to determine the flowering time temperature-sensitivity of 23 Nunavut Arctic plant species and to compare the temperature-sensitivity of conspecifics between the Nunavut archipelago and mainland (above and below the black line), as well as between Baffin Island and Ellesmere Island. Arrows indicate phenology monitoring locations at Lake Hazen and Tanquary Fiord on Ellesmere Island and Iqaluit on Baffin Island.

For each herbarium specimen, I associated the flowering time record with the June mean temperature (in the year the specimen was collected) of the Environment Canada weather station nearest to the collection location (Environment Canada, 2016; Fig. 3). For each species separately, I ran a regression analysis of the flowering time records with the associated June mean temperature over the last 70 years $(1946-2015)$ to determine the flowering time temperature-sensitivity of each of the 23 plant species. I found great diversity in the flowering time temperature-sensitivity of the 23 species (Panchen and Gorelick, in press), and I suggested that the interspecific variation in responsiveness to climate change could lead to altered Arctic ecological community competition, pollinator interactions, and ultimately Arctic ecological community composition (Hegland et al., 2009; McKinney et al., 2012; CaraDonna et al., 2014). The flowering time temperature-sensitivity also varied within a species: for example, plants from the Nunavut archipelago (includes the Boothia and Melville Peninsulas, as well as islands north of Hudson Bay) were more temperature-sensitive than their conspecifics from mainland Nunavut farther south (includes islands with similar latitude and climate), and within the Nunavut archipelago, plants from Baffin Island were more temperature-sensitive than their conspecifics from Ellesmere Island. From these findings, I suggested 
that plants are evolutionarily adapted to the Nunavut region where they grow (van Dijk et al., 1997). My analysis of the weather station temperature records indicated that mean temperatures are rising more significantly towards the end of the growing season (July) and in the late autumn and winter months (September to February) than at the beginning of the growing season (May and June), which reflects the general Arctic climate change pattern and concurs with my Tanquary Fiord temperature analysis.

\section{Elevation Gradient Study}

I used the $1000 \mathrm{~m}$ elevation gradient at Lake Hazen, with its associated temperature gradient, as a proxy for climate change. In 2015, I monitored the flowering and seed dispersal times of seven species at sites along the elevation gradient at Lake Hazen. The seven species I chose were found at multiple sites along the elevation gradient and were a subset of the species I used in my phenology monitoring study at Lake Hazen and in my herbarium specimen study. I used the same method of counting flowers on tagged plants at each site as I had in my earlier phenology monitoring study to determine the peak of flowering and start of seed dispersal of each species at each site. I installed temperature sensors at the sites along the elevation gradient to determine the monthly mean temperatures at each site. I then calculated the temperature-sensitivity of flowering time and seed dispersal time for each species by regressing flowering time with June mean temperature and seed dispersal time with July mean temperature. I found a wide range of flowering time temperature-sensitivity among the seven species, with mountain avens being the most temperature-sensitive. The diversity of flowering time temperature-sensitivity in my elevation gradient study concurs with my herbarium specimen study findings and further supports my hypothesis of altered Arctic ecological community structure with climate change (CaraDonna et al., 2014). As with the Tanquary Fiord long-term phenology monitoring study, I found that the flowering time temperature-sensitivity of mountain avens was twice that of purple saxifrage, and that seed dispersal times of mountain avens showed temperature-sensitivity, while those of purple saxifrage did not. The high flowering and fruiting time temperature-sensitivity of mountain avens calculated in this elevation gradient study and the Tanquary Fiord study suggest that mountain avens will continue to be a dominant species in the Nunavut landscape as the climate warms. In addition, I found that plants at the coldest site at the highest elevation required significantly fewer growing degree days above zero to flower than their conspecifics at lower and warmer elevations, which suggests that the plants at the highest elevation are evolutionarily adapted to the colder, shorter growing season at higher elevations (Olsson and Ågren, 2002).

\section{CONCLUSIONS}

My results indicate that Arctic plant phenology can respond and is responding to the rising temperatures of climate change. I suggest that these responses will occur through phenotypic plasticity in the short term and evolutionary adaptation in the long term (Anderson et al., 2012). I found that reproductive phenological events of Nunavut plants that occur later in the growing season are advancing more than those that occur earlier, reflecting the fact that in the Arctic, late growing season temperatures are rising more than early season temperatures. I also found interspecific and interregional differences in flowering and fruiting time temperature-sensitivity that could lead to altered Arctic ecological community structure. My temperature analysis showed that Nunavut is experiencing a pattern of climate change similar to that of the Arctic in general.

Perhaps the greatest contribution of my research is that these findings are consistent at different spatial scales, from the microclimates at Lake Hazen and Iqaluit to across the 2.1 million $\mathrm{km}^{2}$ area of Nunavut; at different temporal scales, from the 20 -year monitoring study at Tanquary Fiord to the 120-year study of herbarium specimens; and using three different approaches (long-term phenology monitoring records, herbarium specimen historical phenology records, and an elevation gradient as a proxy for climate change).

\section{ACKNOWLEDGEMENTS}

I am honoured to have received the 2016 Jennifer Robinson Memorial Scholarship from the Arctic Institute of North America, without which I could not have completed my research on this remote and beautiful region of Arctic Canada. I would like to thank the Hamlets and Hunter and Trapper Organisations of Grise Fiord, Resolute, and Iqaluit for their support of my research on Inuit land. I thank my PhD thesis advisor, Dr. Root Gorelick, and committee members Dr. Chris Burn and Dr. Lynn Gillespie for their guidance. I thank my field assistants, Sofia Sophia Jain-Schlaepfer, Orla Osborne, Emma Micalizzi, Joan Makaroff, Teresa Tufts, and Carly Casey, and Nunavut community Parks Canada staff who all counted more flowers than they care to remember. I also received funding or logistical support from the Canadian Federation of University Women, Carleton University, Natural Sciences and Engineering Research Council, Northern Scientific Training Program, Ontario Graduate Scholarship Program, Parks Canada's Nunavut Field Unit, and Polar Continental Shelf Program. This research was conducted under Nunavut Department of Environment Wildlife Research Permits WL 2013-039 and WL 2014-021, Nunavut Territorial Parks Park Use Permits 2013-01 PU and 2014-02 PU, and Parks Canada Research and Collections Permits QUT 2013-13959 and QUT-2014-16198. 


\section{REFERENCES}

Abu-Asab, M.S., Peterson, P.M., Shetler, S.G., and Orli, S.S. 2001. Earlier plant flowering in spring as a response to global warming in the Washington, DC, area. Biodiversity \& Conservation 10(4):597-612.

http://dx.doi.org/10.1023/A:1016667125469

Anderson, J.T., Inouye, D.W., McKinney, A.M., Colautti, R.I., and Mitchell-Olds, T. 2012. Phenotypic plasticity and adaptive evolution contribute to advancing flowering phenology in response to climate change. Proceedings of the Royal Society B-Biological Sciences 279(1743):3843-3852.

http://dx.doi.org/10.1098/rspb.2012.1051

Bernier, G., and Périlleux, C. 2005. A physiological overview of the genetics of flowering time control. Plant Biotechnology Journal 3(1):3-16. http://dx.doi.org/10.1111/j.1467-7652.2004.00114.x

Bock, A., Sparks, T.H., Estrella, N., Jee, N., Casebow, A., Schunk, C., Leuchner, M., and Menzel, A. 2014. Changes in first flowering dates and flowering duration of 232 plant species on the island of Guernsey. Global Change Biology 20(11):3508-3519.

http://dx.doi.org/10.1111/gcb.12579

Calinger, K.M., Queenborough, S., and Curtis, P.S. 2013. Herbarium specimens reveal the footprint of climate change on flowering trends across north-central North America. Ecology Letters 16(8):1037-1044.

http://dx.doi.org/10.1111/ele.12135

CaraDonna, P.J., Iler, A.M., and Inouye, D.W. 2014. Shifts in flowering phenology reshape a subalpine plant community. Proceedings of the National Academy of Sciences of the United States of America 111(13):4916-4921.

http://dx.doi.org/10.1073/pnas.1323073111

Clausen, J., Keck, D.D., and Hiesey, W.M. 1941. Regional differentiation in plant species. The American Naturalist 75(758):231-250.

http://dx.doi.org/10.1086/280955

Davis, C.C., Willis, C.G., Connolly, B., Kelly, C., and Ellison, A.M. 2015. Herbarium records are reliable sources of phenological change driven by climate and provide novel insights into species' phenological cueing mechanisms. American Journal of Botany 102(10):1599-1609.

http://dx.doi.org/10.3732/ajb.1500237

Environment Canada. 2016. Historical climate data. http://climate.weather.gc.ca/index_e.html

Fitter, A.H., Fitter, R.S.R., Harris, I.T.B., and Williamson, M.H. 1995. Relationships between first flowering date and temperature in the flora of a locality in central England. Functional Ecology 9(1):55-60. http://dx.doi.org/10.2307/2390090

Hegland, S.J., Nielsen, A., Lázaro, A., Bjerknes, A.-L., and Totland, Ø. 2009. How does climate warming affect plantpollinator interactions? Ecology Letters 12(2):184-195.

http://dx.doi.org/10.1111/j.1461-0248.2008.01269.x
Kimball, K.D., Davis, M.L., Weihrauch, D.M., Murray, G.L.D., and Rancourt, K. 2014. Limited alpine climatic warming and modeled phenology advancement for three alpine species in the northeast United States. American Journal of Botany 101(9):1437-1446.

http://dx.doi.org/10.3732/ajb.1400214

McBean, G. 2005. Arctic climate: Past and present. In: Arctic climate impact assessment: Scientific report. Cambridge: Cambridge University Press. 21-60.

McKinney, A.M., CaraDonna, P.J., Inouye, D.W., Barr, B., Bertelsen, C.D., and Waser, N.M. 2012. Asynchronous changes in phenology of migrating Broad-tailed Hummingbirds and their early-season nectar resources. Ecology 93(9):1987-1993. http://dx.doi.org/10.1890/12-0255.1

Miller-Rushing, A.J., and Primack, R.B. 2008. Global warming and flowering times in Thoreau's Concord: A community perspective. Ecology 89(2):332-341.

http://dx.doi.org/10.1890/07-0068.1

Miller-Rushing, A.J., Primack, R.B., Primack, D., and Mukunda, S. 2006. Photographs and herbarium specimens as tools to document phenological changes in response to global warming. American Journal of Botany 93(11):1667- 1674. http://dx.doi.org/10.3732/ajb.93.11.1667

Molau, U. 1997. Responses to natural climatic variation and experimental warming in two tundra plant species with contrasting life forms: Cassiope tetragona and Ranunculus nivalis. Global Change Biology 3S1):97-107. http://dx.doi.org/10.1111/j.1365-2486.1997.gcb138.x

Molau, U., Nordenhäll, U., and Eriksen, B. 2005. Onset of flowering and climate variability in an alpine landscape: A 10 -year study from Swedish Lapland. American Journal of Botany 92(3):422-431. http://dx.doi.org/10.3732/ajb.92.3.422

Olsson, K., and Ågren, J. 2002. Latitudinal population differentiation in phenology, life history and flower morphology in the perennial herb Lythrum salicaria. Journal of Evolutionary Biology 15(6):983 - 996. http://dx.doi.org/10.1046/j.1420-9101.2002.00457.x

Panchen, Z.A., and Gorelick, R. 2015. Flowering and fruiting responses to climate change of two Arctic plant species, purple saxifrage (Saxifraga oppositifolia) and mountain avens (Dryas integrifolia). Arctic Science 1(2):45-58.

http://dx.doi.org/10.1139/as-2015-0016

Panchen, Z.A., and Gorelick, R. 2016. Canadian Arctic Archipelago conspecifics flower earlier in the High Arctic than the mid-Arctic. International Journal of Plant Sciences 177(8):661-670. http://dx.doi.org/10.1086/687984

- . in press. Prediction of Arctic plant phenological sensitivity to climate change from historical records. Ecology and Evolution.

Panchen, Z.A., Primack, R.B., Aniśko, T., and Lyons, R.E. 2012. Herbarium specimens, photographs, and field observations show Philadelphia area plants are responding to climate change. American Journal of Botany 99(4):751-756.

http://dx.doi.org/10.3732/ajb.1100198 
Rathcke, B., and Lacey, E.P. 1985. Phenological patterns of terrestrial plants. Annual Review of Ecology and Systematics 16:179-214.

http://dx.doi.org/10.1146/annurev.es.16.110185.001143

Stocker, T.F., Qin, D., Plattner, G.-K., Alexander, L.V., Allen, S.K., Bindoff, N.L., Bréon, F.-M., et al. 2013. Technical summary. In: Climate change 2013: The physical science basis. Contribution of Working Group I to the Fifth Assessment Report of the Intergovernmental Panel on Climate Change. Cambridge: Cambridge University Press. 33-115.

Thórhallsdóttir, T.E. 1998. Flowering phenology in the central highland of Iceland and implications for climatic warming in the Arctic. Oecologia 114(1):43-49. http://dx.doi.org/10.1007/s004420050418

Van Dijk, H., Boudry, P., McCombre, H., and Vernet, P. 1997. Flowering time in wild beet (Beta vulgaris ssp. maritima) along a latitudinal cline. Acta Oecologica 18(1):47-60. http://dx.doi.org/10.1016/S1146-609X(97)80080-X
Wagner, I., and Simons, A.M. 2009. Divergence among Arctic and alpine populations of the annual, Koenigia islandica: Morphology, life-history, and phenology. Ecography 32(1): $114-122$. http://dx.doi.org/10.1111/j.1600-0587.2008.05497.x

Weber, E., and Schmid, B. 1998. Latitudinal population differentiation in two species of Solidago (Asteraceae) introduced into Europe. American Journal of Botany 85(8):1110-1121.

http://dx.doi.org/10.2307/2446344

Zoe Panchen is the 2016 recipient of the Jennifer Robinson Memorial Scholarship. Zoe received her PhD from the Department of Biology, Carleton University, Ottawa, Ontario, this past autumn.

E-mail: Zoe.Panchen@carleton.ca 